\title{
The Influence of Marketing Mix on Brand Image, Motivation and Students Decision to Choose Graduate Studies of IPB University
}

\author{
Zukhri Agusty Leo Syamsul Arifin ${ }^{* 1}$, Ujang Sumarwan², Mukhamad Najib ${ }^{3}$ \\ ${ }^{1}$ Business School, IPB University, Bogor 16128, Indonesia \\ ${ }^{2}$ Department of Family and Consumer Sciences, Faculty of Human Ecology, IPB University, \\ Bogor 16680, Indonesia \\ ${ }^{3}$ Department of Management, Faculty of Economics and Management, IPB University, Bogor \\ 16680 , Indonesia \\ *) Corresponding author: zalsa_siregar@apps.ipb.ac.id
}

\begin{abstract}
Competition in the recruitment of graduate students is increasingly tight, with a large number of tertiary institutions offering graduate education programs. Universities must develop more competitive marketing strategies to win the competition in the student recruitment market. The 7Ps marketing mix is one of the marketing concepts that universities can develop to inform the excellence of graduate education that consumers want. This study aims to analyze the effect of the marketing mix on brand-image, motivation, and student decisions in choosing a graduate education at the IPB University as the place to pursue graduate study. This study used a causality approach with survey techniques to explain the causal relationship between marketing mix variables, brand image, motivation, and student decisions. The data of this study were collected using a questionnaire from 255 master program students of IPB. Structural Equation Modeling (SEM) is used to analyze the causal relationship between marketing mix with brandimage, motivation, and student decisions. The results showed that products, promotions, people, and physical evidence significantly influence brand- image. Product, place, process, people, physical evidence, and brand image have a significant influence on motivation. The product, promotion, process, people, brand image, and motivation influence the student's decision. Policy-makers at IPB can consider the findings of this study, while developing a graduate education marketing plan, to increase the number of new students.
\end{abstract}

Keywords: brand image, marketing mix, motivation, SEM-PLS, students' decision

\begin{abstract}
Abstrak
Persaingan dalam perekrutan mahasiswa pendidikan pascasarjana semakin ketat dengan banyaknya perguruan tinggi yang menawarkan program pendidikan pascasarjana. Perguruan tinggi harus mengembangkan strategi pemasaran yang lebih kompetitif untuk memenangkan persaingan dalam pasar perekrutan mahasiswa. Bauran pemasaran 7Ps merupakan salah satu konsep pemasaran yang dapat dikembangkan oleh perguruan tinggi untuk dapat menginformasikan keunggulan pendidikan pascasarjana yang diinginkan konsumen. Penelitian ini bertujuan untuk menganalisis pengaruh bauran
\end{abstract}


pemasaran terhadap brand image, motivasi dan keputusan mahasiswa dalam memilih pendidikan pascasarjana Institut Pertanian Bogor (IPB) sebagai tempat untuk melanjutkan pendidikan pascasarjana. Penelitian ini menggunakan pendekatan kausalitas dengan teknik survei untuk menjelaskan hubungan kausalitas antara variabel bauran pemasaran, brand image, motivasi dan keputusan mahasiswa. Data penelitian ini dikumpulkan dengan menggunakan kuesioner dari 255 orang mahasiswa program magister IPB. Structural Equation Modeling (SEM) digunakan untuk menganalisis hubungan kausalitas antara bauran pemasaran jasa dengan brand image, motivasi dan keputusan mahasiswa. Hasil penelitian menunjukkan bahwa produk, promosi, people, dan bukti fisik berpengaruh secara signifikan terhadap brand image. Variabel produk, tempat, proses, people, bukti fisik, dan brand image memiliki pengaruh signifikan terhadap motivasi. Variabel produk, promosi, proses dan people, brand image, dan motivasi berpengaruh secara signifikan terhadap keputusan mahasiswa. Pembuat kebijakan di IPB dapat mempertimbangkan hasil dari penelitian ini, ketika menyusun rencana pemasaran pendidikan pascasarjana, untuk meningkatkan jumlah mahasiswa baru.

Kata kunci: bauran pemasaran, brand image, keputusan mahasiswa, motivasi, SEM

\section{Introduction}

Globalization is a process of formation of a new world order that requires mutual adjustment and also results in the creation of competitive circumstances, which is increasing in various areas, including in higher education services. Globalization causes the higher education market to become borderless. Universities face competition, not only with domestic higher education but also with foreign universities in recruiting students.

Table 1 The number of study programs in higher education in Indonesia

\begin{tabular}{lcccccccc}
\hline \multirow{2}{*}{ Field } & \multicolumn{2}{c}{ Diploma } & \multicolumn{2}{c}{ S-1 } & \multicolumn{3}{c}{ S-2 } & \multicolumn{3}{c}{ S-3 } \\
\cline { 2 - 8 } & Public & Private & Public & Private & Public & Private & Public & Private \\
\hline Religion & - & - & 109 & 369 & 29 & 121 & 11 & 38 \\
Humaniora & 53 & 85 & 196 & 211 & 48 & 11 & 14 & 2 \\
Social & 169 & 360 & 609 & 1528 & 270 & 243 & 84 & 29 \\
Sains & 40 & 98 & 259 & 191 & 87 & 7 & 38 & 1 \\
Art & 40 & 55 & 71 & 123 & 12 & 6 & 4 & - \\
Health & 462 & 1265 & 111 & 543 & 79 & 26 & 22 & - \\
Technique & 553 & 1099 & 396 & 1864 & 126 & 86 & 56 & 5 \\
Agriculture & 158 & 39 & 350 & 637 & 172 & 27 & 65 & - \\
Economy & 138 & 106 & 271 & 1.495 & 133 & 231 & 48 & 16 \\
Education & - & 429 & 1.135 & 2.438 & 327 & 187 & 79 & 8 \\
\hline All & 1.613 & 3.536 & 3.507 & 9.399 & 1.283 & 945 & 421 & 99 \\
\hline Source: Ditjen DIKTI 2014 in Kompas Daily Monday 19 January 2015 &
\end{tabular}

Source: Ditjen DIKTI, 2014 in Kompas Daily Monday 19 January 2015

The graduate education program is one of the educational services offered by universities. Universities that organize graduate education have become one of the centers of education, which are important, given that the market's need for graduate education graduates is getting dynamic lately, in line with the demand for competent workforces from both national and multinational enterprises. Graduate qualifications 
become mandatory in most positions of the level of enterprise and directors in large companies (Subramaniam, Yusoff, \& Arumugam, 2014).

The increasing need for graduate education in Indonesia is the opportunity for higher education institutions to develop graduate education. In the last two decades, universities that hold graduate education programs are increasing throughout the world, including in Indonesia. Table 1 shows the number of major courses for the master's degree program in 2014 as many as 2.228 and the number of major courses for the doctoral degree program in 2014 as many as 520 . The number of departments organized by higher education institutions automatically leads to unavoidable and very tight competition.

Competition is getting tougher, given that foreign universities are doing direct promotion to attract students and professionals in Indonesia to attend graduate school at their universities. In 2016 LPDP Edufair conducted by the Institute of Education Fund Management (LPDP), nearly 50 foreign universities offered their graduate education programs. The increasing number of overseas scholarships available to support those who wish to pursue graduate programs abroad, such as scholarships LPDP.

The graduate education programs offered by foreign and tertiary institutions provide many options for students to pursue graduate education. Higher education institutions must put in place strategies that can provide clear information about the graduate education offered to consumers. Through understanding consumers' behaviors and perceptions, higher education management can develop appropriate strategies and programs to take advantage of existing opportunities. Understanding consumer behavior and getting to know customers is an important task for marketers whose aim is to achieve a purchasing decision, in this case, the decision of prospective students to choose a college.

One factor that can influence consumer decisions is the marketing strategy developed by a company. Ming (2010) states that universities must look for more competitive marketing strategies to win the competition in the student recruitment market. One of the marketing concepts that offer solutions and a tool to achieve goals in a market with competition and different perceptions of service and quality is the marketing mix (Constantin, 2011). Furthermore, Constantin (2011) stated that by using templates of 7 Ps (product, price, place, promotion, process, people, and physical evidence), the university would be able to make a coherent marketing mix, will be capable of overcoming the goal. Through a marketing mix developed and directed at the target market, universities can inform the advantages of graduate education that consumers want. Based on this information, prospective students can determine their future by continuing graduate education at the tertiary institution.

In addition to the marketing mix, universities can also utilize campus brand image to influence consumer decisions. Brand image is related to consumer satisfaction with product quality in providing satisfaction to consumers. Brand image is one of the things that become the basis for consumers to choose products, both goods, and services, to meet their needs. Likewise in the selection of higher education institutions, Subramaniam, Yusoff, and Othman (2014) showed a significant differences between the knowledge of university brands and the decision to improve education at the university.

The decision to continue education at certain universities is not a coincidence, but through a buying decision process. Consumer motivation is a determining variable in the direction of purchasing behavior for a product. Every company wants any product offered in the market so that it can be accepted, bought, and consumed. Tereza (2013) 
showed that differences in motivation that underlie students to pursue higher education had a positive effect on the choice of universities to continue their studies. Skatova and Ferguson (2014) showed that students' motivation to pursue different undergraduate education influences the choice of bachelor's degree.

A study on consumer behavior, especially about the choice and student decisionmaking process, helps the higher educations have a clear understanding of the student recruitment market (Maringe, 2006). Previous research studies provided an understanding of the effect of the marketing mix on students' decisions in choosing educational services, either directly or through intervening variables, which are found by researchers in various countries. Several studies have examined the effect of marketing mix on decision making (Sefnedhi, 2013; Kurniawati, 2013; Irawan \& Faisal, 2014; Yenida, Sumiarti, \& Sarmiadi, 2015; Sukendar, 2015; Podungge, Bachri \& Zahara, 2016; Samani, Hashemi, Shahbazi, \& Sarhadi, 2017; Armeilia, Simanjuntak, \& Amanah, 2019; Simanjuntak, Sumarwan \& Situmorang, 2020; Arthur, Asmara, \& Simanjuntak, 2019). Meanwhile, Rahardjo and Firdaus (2016) examined the effect of the marketing mix on the decision to choose through motivation as an intervening variable. Sunariani (2017) and Winarti (2014) examined the effect of marketing mix on the decision to choose through the brand image as an intervening variable. Another study by Sawaji, Hamzah, and Taba (2010), examined the effect of price and marketing communication and reference groups on decision making through the brand image, attitude, and motivation as intervening variables. This study differs from previous studies regarding the effect of the marketing mix on the decision to choose educational services. This study looks at the effect of all marketing mix variables on student decisions and through brand image and motivation as intervening.

The tight competition in the purchase of educational service gives effect to the IPB University to recruit new students. IPB is holding graduate education programs. Seeing the number of development data of student candidates who apply and the number of students accepted in table 2, there was a decrease in the enrollment period of 2014/2015 and 2016/2017, after having increased previously. This condition needs to be considered by all stakeholders in IPB to prevent the decreasing.

Table 2 The progress of applicants and new student Graduate School of IPB

\begin{tabular}{lrrrrrrrrrr}
\hline \multirow{2}{*}{ Faculties } & \multicolumn{2}{c}{$2012-2013$} & \multicolumn{2}{c}{$2013-2014$} & \multicolumn{2}{c}{$2014-2015$} & \multicolumn{2}{c}{$2015-2016$} & \multicolumn{2}{c}{$2016-2017$} \\
\cline { 2 - 9 } & Apply & Accept & Apply & Accept & Apply & Accept & Apply & Accept & Apply & Accept \\
\hline Faperta & 205 & 173 & 322 & 264 & 196 & 164 & 286 & 280 & 220 & 214 \\
FKH & 55 & 45 & 98 & 70 & 55 & 49 & 110 & 110 & 70 & 69 \\
FPIK & 197 & 171 & 259 & 215 & 237 & 196 & 255 & 250 & 218 & 212 \\
Fapet & 63 & 55 & 83 & 72 & 73 & 56 & 89 & 88 & 68 & 68 \\
Fahutan & 93 & 79 & 96 & 89 & 104 & 88 & 142 & 146 & 88 & 86 \\
Fateta & 135 & 110 & 178 & 158 & 149 & 106 & 258 & 235 & 175 & 167 \\
FMIPA & 313 & 230 & 504 & 393 & 439 & 269 & 547 & 445 & 351 & 295 \\
FEM & 186 & 140 & 228 & 181 & 183 & 131 & 338 & 295 & 200 & 182 \\
FEM & 123 & 102 & 122 & 87 & 130 & 84 & 230 & 188 & 159 & 133 \\
Multi & 70 & 58 & 137 & 107 & 91 & 61 & 172 & 161 & 121 & 115 \\
\hline All & 1440 & 1163 & 2027 & 1636 & 1657 & 1204 & 2427 & 2198 & 1670 & 1541 \\
\hline Source: PPMB & SPS IPB (2012-2016) & & & & & & &
\end{tabular}

To win the fierce competition, IPB must have a marketing strategy that provides a competitive advantage. By understanding the factors influencing the decision to

choose graduate education, IPB can create a marketing strategy policy that fits the target 
market to increase the number of students accepted.

Based on the description above, this study aims to analyze the factors that influence the marketing mix that affects the brand image, motivation, and decision of students in choosing graduate education of IPB and its implications for the development of marketing strategies of the graduate program of IPB to increase the number of new student admissions.

\section{Methods}

The study was conducted at the IPB University in December 2016 to January 2017. The sample of the study was the graduate education of IPB, and the population of this study was students of graduate education of IPB in the academic year of 2016-2017. Sampling was conducted using stratified random sampling. Samples were grouped into three groups based on the average number of new students accepted. The sample size required to estimate using SEM-PLS was ten times the largest amount of structural path directed at a particular construct in structural models (Ghozali, 2008). In this study, the structural path formed was 24 lines, so the number of samples taken a minimum of 240 respondents. The number of samples taken in this study was 255 respondents.

The variables in this study consisted of the dependent variable (endogenous) and the independent variable (exogenous). Endogenous variables include brand image (Y1), student motivation (Y2), and student decisions (Y3). Exogenous variables include the product $(\mathrm{X} 1)$, price $(\mathrm{X} 2)$, place $(\mathrm{X} 3)$, promotion $(\mathrm{X} 4)$, process $(\mathrm{X} 5)$, people $(\mathrm{X} 6)$, and physical evidence (X7). Table 3 shows the operational definitions of the variables and their indicators.

Table 3 The Variable and indicators

\begin{tabular}{|c|c|c|c|}
\hline Variable & Operational Definition & Indicators & Symbol \\
\hline $\begin{array}{l}\text { Product } \\
\text { (X1) }\end{array}$ & $\begin{array}{l}\text { The graduate education } \\
\text { program offered to students }\end{array}$ & $\begin{array}{l}\text { Study programme } \\
\text { Accreditation } \\
\text { Curriculum } \\
\text { Cooperation in education } \\
\text { Research }\end{array}$ & $\begin{array}{l}\text { PRODUCT1 } \\
\text { PRODUCT2 } \\
\text { PRODUCT3 } \\
\text { PRODUCT4 } \\
\text { PRODUCT5 }\end{array}$ \\
\hline Price (X2) & $\begin{array}{l}\text { Everything related to the } \\
\text { cost of graduate education }\end{array}$ & $\begin{array}{l}\text { Relative education cost } \\
\text { Availability of scholarships }\end{array}$ & $\begin{array}{l}\text { PRICE1 } \\
\text { PRICE2 }\end{array}$ \\
\hline Place (X3) & $\begin{array}{l}\text { The location and the } \\
\text { university environment }\end{array}$ & $\begin{array}{l}\text { Strategic location } \\
\text { Reachable by public transportation } \\
\text { Near to the center of government and } \\
\text { business }\end{array}$ & $\begin{array}{l}\text { PLACE1 } \\
\text { PLACE2 } \\
\text { PLACE3 }\end{array}$ \\
\hline $\begin{array}{l}\text { Promotion } \\
\text { (X4) }\end{array}$ & $\begin{array}{l}\text { All of the activities to } \\
\text { communicate the graduate } \\
\text { education to the public }\end{array}$ & $\begin{array}{l}\text { Mass media } \\
\text { Print media (banners, leaflets, etc.) } \\
\text { Graduate education fairs } \\
\text { Websites } \\
\text { Social media }\end{array}$ & $\begin{array}{l}\text { PROMOTION1 } \\
\text { PROMOTION2 } \\
\text { PROMOTION3 } \\
\text { PROMOTION4 } \\
\text { PROMOTION5 }\end{array}$ \\
\hline $\begin{array}{l}\text { Process } \\
(\mathrm{X} 5)\end{array}$ & $\begin{array}{l}\text { The activity in delivering } \\
\text { graduate education services }\end{array}$ & $\begin{array}{l}\text { process of registration of new } \\
\text { students } \\
\text { the learning process } \\
\text { guardianship of thesis }\end{array}$ & $\begin{array}{l}\text { PROCESS1 } \\
\text { PROCESS2 } \\
\text { PROCESS3 }\end{array}$ \\
\hline
\end{tabular}


Arifin, Sumarwan, \& Najib / Journal of Consumer Sciences, 2020, Vol. 05, No. 02

Table 3 The Variable and indicators (cont..)

\begin{tabular}{|c|c|c|c|}
\hline Variable & Operational Definition & Indicators & Symbol \\
\hline & & the process of administrative services & PROCESS4 \\
\hline People & a variable that describes & lecturer's quality and competence & PEOPLE1 \\
\hline \multirow[t]{2}{*}{$(\mathrm{X} 6)$} & \multirow{2}{*}{$\begin{array}{l}\text { people who are directly } \\
\text { involved in the process of } \\
\text { graduate education services }\end{array}$} & lecturer's capability and & PEOPLE2 \\
\hline & & $\begin{array}{l}\text { abilities of employees in providing } \\
\text { administrative services }\end{array}$ & PEOPLE3 \\
\hline $\begin{array}{l}\text { Physical } \\
\text { evidence }\end{array}$ & $\begin{array}{l}\text { The facilities and } \\
\text { infrastructure to support the }\end{array}$ & $\begin{array}{l}\text { a comfortable and conducive } \\
\text { environment }\end{array}$ & PHYS.EVID1 \\
\hline \multirow[t]{3}{*}{$(\mathrm{X} 7)$} & \multirow{3}{*}{$\begin{array}{l}\text { provision of graduate } \\
\text { education services }\end{array}$} & academic facilities & PHYS.EVID2 \\
\hline & & support facilities & PHYS.EVID3 \\
\hline & & internet access & PHYS.EVID4 \\
\hline \multirow{4}{*}{$\begin{array}{l}\text { Brand } \\
\text { image (Y1) }\end{array}$} & \multirow{4}{*}{$\begin{array}{l}\text { an overview of graduate } \\
\text { education of IPB in } \\
\text { student's point of view }\end{array}$} & \multirow{3}{*}{\multicolumn{2}{|c|}{$\begin{array}{l}\text { the reputation of graduate education BR.IMAGE1 the } \\
\text { quality and development research } \\
\text { competitive graduates } \\
\text { BR.IMAGE2 }\end{array}$}} \\
\hline & & & \\
\hline & & & \\
\hline & & $\begin{array}{l}\text { complete facilities \& conducive } \\
\text { environment }\end{array}$ & BR.IMAGE4 \\
\hline \multirow{4}{*}{$\begin{array}{l}\text { Student } \\
\text { motivation } \\
(\mathrm{Y} 2)\end{array}$} & \multirow{4}{*}{$\begin{array}{l}\text { what encourages students to } \\
\text { choose graduate education } \\
\text { of IPB }\end{array}$} & $\begin{array}{l}\text { desiring of studying at a renowned } \\
\text { university }\end{array}$ & MOTIVATION1 \\
\hline & & $\begin{array}{l}\text { increasing knowledge in the wake of } \\
\text { career competition }\end{array}$ & MOTIVATION2 \\
\hline & & $\begin{array}{l}\text { Getting accepted in department } \\
\text { desired and personal pride }\end{array}$ & MOTIVATION3 \\
\hline & & Social status & MOTIVATION4 \\
\hline \multirow{3}{*}{$\begin{array}{l}\text { Student } \\
\text { decisions } \\
\text { (Y3) }\end{array}$} & \multirow{3}{*}{$\begin{array}{l}\text { The decision-making } \\
\text { process to choose graduate } \\
\text { education of IPB }\end{array}$} & Registering the process as the student & STU.DECISION1 \\
\hline & & Being a student & STU.DECISION2 \\
\hline & & Recommending to others & STU.DECISION3 \\
\hline
\end{tabular}


Data was collected using a set of questionnaire. The form of questions in the questionnaire is semi-open and closed. The answer to the question is made on a Likert scale consisting of strongly disagree (1), disagree (2), indifferent (3), agree (4), and strongly agree (5). The distribution of questionnaires was done in two ways, namely online and offline, either directly to respondents or through study program staff from the respondents. The data obtained is then processed by the process of input, editing, coding, cleaning, and data analysis. Applications used in data processing and analysis are Microsoft Excel 2013 and Smart PLS 3.0. Quantitative descriptive analysis is used to describe the characteristics of master students (S2) respondents. Causality analysis is done to analyze the relationship and influence of marketing mix variables with the brand image, motivation, and decision to choose graduate education.

\section{Findings}

\section{Characteristics of Respondents}

Table 4 shows the description of respondent characteristics in this study. The proportion of male and female respondents was $43.92 \%$ and $56.08 \%$. The majority of respondents' age when getting accepted at SPS of IPB was 20-25 years (70.20\%). Then respondents aged 26-30 years (14.12\%), aged 31-35 (10.98\%), aged 36-40 (3.92\%) and aged over 40 as much as $0.78 \%$.

Most respondents are from Java, Bali, and Nusa Tenggara (30.20\%). The next most respondents were from the Jabodetabek-Banten (25.88\%), Maluku and Papua $(15.29 \%)$, Sulawesi $(14.12 \%)$, Sumatera $(11.37 \%)$ and lastly Kalimantan as much as $3.14 \%$. The proportion of the number of respondents based on students' undergraduate university was from not-IPB $68.24 \%$ and IPB $31.76 \%$. The proportion based on finance sources was non-scholarship (63.92\%) and scholarships $(36.08 \%)$. Based on working status when registering at SPS of IPB, the proportion of respondents was unemployed $(50.59 \%)$ and employed $(49.41 \%)$.

Table 4 Characteristics of Respondents

\begin{tabular}{llrr}
\hline Characteristics of Respondents & Frequency & \% \\
\hline Gender & Male & 112 & 43.92 \\
Age (year) & Female & 143 & 56.08 \\
& $20-25$ & 179 & 70.20 \\
& $26-30$ & 36 & 14.12 \\
& $31-35$ & 28 & 10.98 \\
Origin & $36-40$ & 10 & 3.92 \\
& $>40$ & 2 & 0.78 \\
& Sumatera & 29 & 11.37 \\
& Jabodetabek Banten & 66 & 25.88 \\
& Jawa, Bali dan Nusa Tenggara & 77 & 30.20 \\
University & Kalimantan & 8.14 \\
& Sulawesi & 36 & 14.12 \\
Sources of Financing & Maluku dan Papua & 39 & 15.29 \\
\multirow{3}{*}{ Employment Status } & IPB & 81 & 31.76 \\
& Not IPB & 174 & 68.24 \\
& Not Scholarships & 163 & 63.92 \\
& Scholarships & 92 & 36.08 \\
& Not Working & 129 & 50.59 \\
& Working & 126 & 49.41 \\
\hline
\end{tabular}

Analysis of Structural Equation Modeling (SEM).

Structural Equation Modelling (SEM) with the method of Partial Least Square 
(PLS) was used to test the model and hypotheses about the relationship between the constructs in this study. PLS model was built and evaluated based on two fundamental tests, which were the measurement model (outside the model) and the evaluation of the structural model (inner model). The measurement of the evaluation model was conducted to test the validity and reliability of the models. The evaluation of the structural model (inner model) was to predict the causal relationship between the latent variables, both exogenous and endogenous.

\section{Evaluation of Measurement Model (Outer Model).}

Convergent validity of the measurement model with reflective indicators was evaluated by the loading factor parameter (the correlation between the indicators and their latent constructs) and the AVE value (measuring the number of variances that can be captured by the constructs compared to the variance caused by the measurement error). The result of the measurement model showed the indicator obtained load factor $>0.5$, and the variable of promotion (PROMOTION2) had AVE value <0.5. AVE value $<0.5$ indicated that the model had not fulfilled convergent validity so that it needs respecification. The re-specification model was done by releasing indicators at the variable of promotion (PROMOTION2) with the lowest value of the loading factor. The result of re-specification indicated that indicators had fulfilled convergent validity with the value of the loading factor from each indicator more than 0.50 (Figure 1) and the AVE value of each variable more than 0.50 (Table 5).

Table 5 The result of the validity and reliability

\begin{tabular}{lccc}
\hline \multicolumn{1}{c}{ Variables } & AVE & Cronbachs Alpha & Composite Reliability \\
\hline Brand Image & 0.686 & 0.845 & 0.897 \\
Price & 0.710 & 0.613 & 0.829 \\
Stu.Decision & 0.777 & 0.848 & 0.898 \\
Phys.Evid & 0.630 & 0.805 & 0.872 \\
Place & 0.627 & 0.704 & 0.834 \\
Motivation & 0.655 & 0.821 & 0.883 \\
Product & 0.643 & 0.860 & 0.900 \\
Promotion & 0.541 & 0.737 & 0.822 \\
Process & 0.561 & 0.739 & 0.836 \\
People & 0.687 & 0.772 & 0.868 \\
\hline
\end{tabular}

Furthermore, testing for discriminant validity is carried out on the principle that the constructors' manifesters of different constructs should not be highly correlated (Ghozali, 2008). The comparison of AVE root values and correlation coefficients between variables can indicate that the model meets the discriminant validity requirements. This is caused by the overall correlation value between constructs less than the root value AVE. The discriminant validity of the model can also be evaluated based on the criteria of crossloading. The cross-loading criterion shows the value of each indicator in the latent variable is different from the other indicator variables, which is indicated by the loading value of the indicator in a block of the construct in question is greater than the loading value in other constructs. Based on these two parameters, the model had fulfilled the discriminant validity criteria.

Composite Reliability indicates that the indicators have high consistency in measuring the latent constructs. In this study, the reliability test was performed with parameters of Cronbach alpha and composite reliability. A latent variable is said to be reliable if its value of Cronbach alpha and composite reliability more than 0.60 and AVE value more than 0.5 (Ghozali, 2008). The model showed all latent constructs had good reliability, accuracy, and consistency because it had fulfilled the criteria by the value of reliability and Cronbach alpha at each latent construct more than 0.6 and the AVE value 
greater than 0.5 (Table 5). The output of the evaluation of the measurement model is presented in Figure 1.

\section{Evaluation of Structural Model (Inner Model)}

The structural model in PLS-SEM was evaluated with R-square and path coefficient estimation. The R-square of endogenous latent variables is endogenous construct variability that can be explained by the variability of exogenous constructs. Path coefficient estimation is the evaluation of the value of the coefficient, including real influence through bootstrapping and the value of the coefficient.

From the analysis of the structural model (inner model), based on the results of data processing (Figure 1), the result of the R-square value of the brand image was 0.751 indicating the model had a good criterion to describe the brand image variable. The Rsquare value of the motivation variable (0.619) and the decision to choose (0.607) had a value of less than 0.67 and more than 0.33 . According to Ghozali (2008), the model had a moderate criterion to explain the Motivation variable and decision to choose.

The value of path coefficients showed a significant level of hypothesis testing. The value of path coefficients shown by t-statistic must be above 1.96 for the two-tailed hypothesis for the confidence level of 95 percent (alpha 5 percent). If the value of $t-$ statistics is higher than the t-table, it means that the hypothesis is supported. The Path coefficient of the bootstrapping procedure results in the Smart PLS 3, as shown in table 6 was to look at the significance of the effect of each exogenous latent variable toward

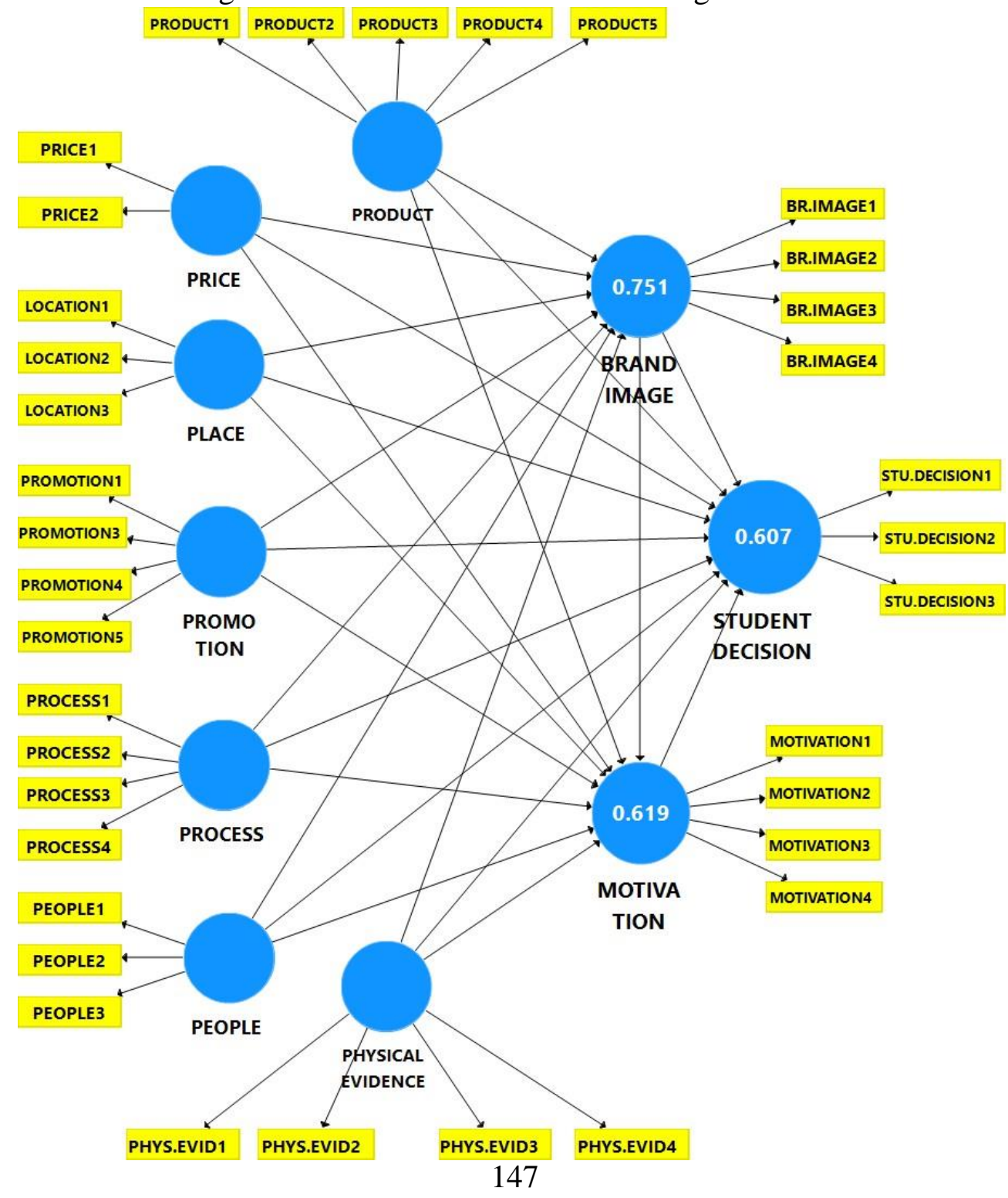


endogenous latent variable by looking at the value of the coefficient parameter (original sample).

\section{Figure 1. SEM model}

Based on Table 6, the product variable, promotion, people, and physical evidence had a significant positive influence on the variable of brand image. This was indicated by the value of the $\mathrm{t}$-statistic greater than the $\mathrm{t}$-table (significance at $\mathrm{t}$-table $5 \%$ =1.96). The result also showed that the price, place, and process had no significant effect on brand image. The variable that had the greatest positive influence was the product by 0.368 . Another variable that had a significant positive influence was the product $(0.324)$, physical evidence (0.218), and promotion (0.100).

The product variable, place, process, and brand image had a significant influence on motivation. In comparison, variable of people and the physical environment had a significant direct influence on motivation through brand image. The result also showed that the price and promotion had no significant effect on motivation, either directly or indirectly. The variable that had the greatest positive influence was the product by 0.365 . Another variable that had a significant positive influence was the brand image (0.258), process (0.154), and location (0.108).

The result indicated that promotion and motivation had a significant influence on student's decisions because they had a greater t-statistic than the t-table. The price, place and physical environment did not influence the student's decisions. While variable of product, process, and brand image had indirectly significant influence. The interesting thing was shown by the people variable. The study showed that people had no direct or indirect influence on the student's decision, but had a significant total influence on the student's decision. The variable that had the most direct influence on a student's decision was the motivation variable by the value of path coefficients of 0.410 . Variable of promotion with the value of path coefficients of 0.130 had a direct positive influence the second only variable of motivation.

\section{Discussion}

The result of the study showed that the graduate education program had a significant influence on the brand image of graduate education. This result indicates the product of graduate education is one component of the marketing mix that is very influential in the brand image of the graduate education of IPB. The indicator that contributed the greatest to a product variable was department curriculum that was oriented to the development of science and the needs of the workforce. Different research results found in the research of Kurniatun and Rosalin (2018), namely product has a significant effect on brand image.

The results showed that the program significantly affected students' motivation to choose postgraduate education. This indicated that the graduate education program offered by IPB is an answer to the respondents in the effort to satisfy their need for graduate education. Motivation appears because of the need perceived by consumers that appear because the consumers feel discomfort (Sumarwan, 2015). These respondents felt that their needs will be fulfilled by continuing to study at the graduate education of IPB. This research was supported by research by Wandy and Dharmayanti (2014), which stated that the product had a significant effect on consumer motivation for Mie Lopo Timor products. Sarianti and Atris (2013) showed different results where the product had no significant effect on consumer purchasing motivation.

The program had no significant direct influence on the student's decision to choose 
the graduate education but had a significant indirect influence. This may be implied that the graduate education program offered was not the determining factor that directly influenced the student's decision. However, the variable of the program had an indirect influence on a student's decision through brand image and motivation. The explanation for this is the student's decision to choose the graduate education of IPB was affected by high student motivation. The increasing motivation of these students was due to the high trust of the brand image of IPB and the student's perceptions of the quality of graduate education programs of IPB. The results of research showing that products influence student choices are found in the research of Kurniawati (2013), Sefnedi (2013), and Zain, Jan, and Ibrahim (2013).

Table 6 Path Coefficient

\begin{tabular}{|c|c|c|c|c|c|c|}
\hline & \multicolumn{2}{|c|}{ Direct Effects } & \multicolumn{2}{|c|}{ Indirect Effects } & \multicolumn{2}{|c|}{ Total } \\
\hline & $\begin{array}{l}\text { Original } \\
\text { Sample }\end{array}$ & $\begin{array}{l}\text { T-Sta- } \\
\text { tistics }\end{array}$ & $\begin{array}{l}\text { Original } \\
\text { Sample }\end{array}$ & $\begin{array}{l}\text { T-Sta- } \\
\text { tistics }\end{array}$ & $\begin{array}{l}\text { Original } \\
\text { Sample }\end{array}$ & $\begin{array}{l}\text { T- Sta- } \\
\text { tistics }\end{array}$ \\
\hline Product ->Brand Image & 0.324 & $5.129 *$ & & & 0.324 & $5.129 *$ \\
\hline Price ->Br.Image & 0.062 & 1.608 & & & 0.062 & 1.608 \\
\hline Place ->Br.Image & -0.060 & 1.530 & & & -0.060 & 1.530 \\
\hline Promotion ->Br.Image & 0.100 & $2.210 *$ & & & 0.100 & $2.210 *$ \\
\hline Process ->Br.Image & 0.048 & 0.869 & & & 0.048 & 0.869 \\
\hline People ->Br.Image & 0.368 & $6.292 *$ & & & 0.368 & $6.292 *$ \\
\hline Phys.Evid ->Br.Image & 0.218 & $4.580^{*}$ & & & 0.218 & $4.580 *$ \\
\hline Product ->Motivation & 0.365 & $4.846^{*}$ & 0.084 & $2.797^{*}$ & 0.449 & $6.740 *$ \\
\hline Price -> Motivation & -0.015 & 0.290 & 0.016 & 1.387 & 0.001 & 0.023 \\
\hline Place ->Motivation & 0.108 & $2.524 *$ & -0.015 & 1.432 & 0.093 & $2.174 *$ \\
\hline Promotion ->Motivation & 0.070 & 1.449 & 0.026 & 1.591 & 0.096 & 1.951 \\
\hline Process ->Motivation & 0.154 & $2.387^{*}$ & 0.012 & 0.751 & 0.166 & $2.533^{*}$ \\
\hline People ->Motivation & 0.027 & 0.337 & 0.095 & $2.452 *$ & 0.122 & 1.710 \\
\hline Phys. Evid ->Motivation & -0.007 & 0.118 & 0.056 & $2.425^{*}$ & 0.050 & 0.923 \\
\hline Br.Image ->Motivation & 0.258 & $2.763 *$ & & & 0.258 & $2.763^{*}$ \\
\hline Product ->Stu.Decision & 0.108 & 1.360 & 0.193 & $4.047^{*}$ & 0.301 & $4.349 *$ \\
\hline Price ->Stu.Decision & 0.045 & 0.925 & 0.002 & 0.090 & 0.047 & 0.981 \\
\hline Place ->Stu.Decision & 0.044 & 1.018 & 0.036 & 1.795 & 0.080 & 1.720 \\
\hline Promotion ->Stu.Decision & 0.130 & $2.350 *$ & 0.042 & 1.642 & 0.172 & $3.133^{*}$ \\
\hline Process ->Stu.Decision & 0.124 & 1.785 & 0.070 & $2.131^{*}$ & 0.193 & $2.646^{*}$ \\
\hline People ->Stu.Decision & 0.090 & 1.130 & 0.060 & 1.214 & 0.150 & $2.087 *$ \\
\hline Phys.Evid ->Stu.Decision & -0.003 & 0.060 & 0.026 & 0.868 & 0.023 & 0.368 \\
\hline Br.Image ->Stu.Decision & 0.027 & 0.264 & 0.106 & $2.291 *$ & 0.132 & 1.176 \\
\hline Motivation ->Stu.Decision & 0.410 & $5.266^{*}$ & & & 0.410 & $5.266^{*}$ \\
\hline Product -> Br.Image & 0.324 & $5.129 *$ & & & 0.324 & $5.129 *$ \\
\hline Price ->Br.Image & 0.062 & 1.608 & & & 0.062 & 1.608 \\
\hline Place ->Br.Image & -0.060 & 1.530 & & & -0.060 & 1.530 \\
\hline Promotion ->Br.Image & 0.100 & $2.210^{*}$ & & & 0.100 & $2.210 *$ \\
\hline
\end{tabular}

* significant if t-statistic $>$ t-table $\alpha=5 \%(1.96)$

The study showed that the price had not significantly influenced the brand image. Brand image is what is perceived by the customers. The policy of tuition fees for graduate education led to a poor perception of students. The students felt the tuition fee of graduate education of IPB was relatively more expensive compared to other state universities. This can be explained that the students felt the rising cost of graduate education, with the implementation of the single tuition fee (UKT) in 2015, was not followed by the quality of services given. Different research results found in the research of Sawaji et al. (2010) and Wibisono (2014), namely price has a significant effect on brand image. According to Filip (2010), the pricing policy will have an impact on the brand image of the university as some consumers perceive the more expensive services, the more substance value.

The price variable had no significant effect on the student's motivation to choose graduate education. This result indicated that the price was not one of the boosters of 
students in choosing the graduate education of IPB. The tuition fee policy change did not affect the student's motivation to choose graduate education of IPB. The results of this study differ from the results of the study of Sawaji et al. (2010), and Wandy and Dharmayanti (2014), which shows that price has a significant influence on motivation. The result showed the price variable did not significantly influence the student's decision to choose an education graduate. In making decisions, the students did not consider price as an important factor. This can be positively interpreted as students did not choose to attend graduate school for a relatively affordable price or availability of scholarships, but because of other factors such as their high motivation. The results of this study are in accordance with the study by Sefnedi (2013), Kurniawati (2013), and Yenida et al. (2015). Research conducted by Ming (2010), Sawaji et al. (2010), Irawan and Faisal (2014), Dao and Thorpe (2015), and Sukendar (2015) showed different results, namely price significantly affected students' decisions.

The location of graduate education did not significantly affect the brand image of graduate education. The location, which is strategic, reachable by public transport and located near the center of government and business, had less contribution in shaping the brand image of the education degree of IPB. The university location was less considered as important in deciding to choose the education graduate of IPB. The study by Kurniatun and Rosalin (2018) showed a different result the location had a significant effect on the University's image.

The location of graduate education had a significant effect on the student's motivation. This meant that the respondents perceived the location of graduate education quite well, thus increasing the motivation to choose IPB. Putlia and Ihalau (2017) stated that strategic location would increase the influence of prospective motivation in making service choices of higher education. Wandy and Dharmayanti (2014) stated that the product had a significant effect on consumer motivation.

The results also showed that the university location did not significantly influence the student's decision to choose graduate education. The result showed that the respondents did not consider university location in deciding to choose. However, a study by Irawan and Faisal (2014), Hariyani and Sartana (2014), Sukendar (2015), Yenida et al. (2015), and Podungge et al. (2016) showed a different result that was the place variable significantly influenced the decision to choose.

The study result stated that the promotion variable had a significant effect on brand image. These results indicate that graduate education promotion activities have an important role in shaping the graduate education brand image. Sawaji et al. (2010) stated that marketing communication significantly influences the image of private universities. A study conducted by Hermanda, Sumarwan, and Tinaprilla (2019) showed that social media influencers had a positive and significant relationship to brand image.

The promotion of graduate education did not significantly influence the student's motivation. This can be interpreted that the promotion conducted by IPB had not been able to increase the motivation of student candidates to study in IPB. Effective promotion can be developed by trying to understand the needs and desires of students related to graduate education. This result was in line with the research conducted by Sawaji et al. (2010), stating that marketing communication had no significant influence on motivation. Other studies showed different results, namely the promotion variable had a significant influence on motivation (Sarianti \& Atris, 2013; Aji, Djawahir, \& Rofiq, 2019; Wandy and Dharmayanti, 2014)

The result showed that the promotion of graduate education had a significant influence on a student's decision to choose graduate education. This may imply that the 
promotional activities of graduate education influenced the decision-making process of students. Information obtained from promotional activities was one of the important elements to be considered by students in making decisions. The study result was in accordance with a study by Sawaji et al. (2010), Sefnedi (2013), and Zain et al. (2013), who found that the promotion variable significantly influenced the student's decision.

The brand image of graduate education had no significant relationship with the process of graduate education. This showed that students took less consideration of the educational process of graduate education in deciding to choose. A study by Wibisono (2014) showed a different result the process had a significant effect on university image. The result showed that the process of education degree had a significant impact on the student's motivation. This showed that the better the students' perceptions of the graduate education process, the more improving the student's motivation to study at the graduate education of IPB. The study results are in line with the research results of Rahardjo and Firdaus (2016), which stated that there is an influence of process variables on student motivation.

The student's decision to choose an education graduate had not been directly signed by the process of graduate education. However, the educational process had an indirect influence positively and significantly to the student's decision. The result of this study indicated that the process of graduate education was not an important factor that determined the student's decision to choose. The educational process was one that encourages students to consider IPB as one of the places to continue graduate education. It was supported by the result of a study by Yenida et al. (2015), which stated the variable of the process did not significantly influence the student's decision. In another study, it was shown a different result, in which the process variable significantly influenced the student's decision (Kurniawati, 2013; Sefnedi, 2013; Irawan \& Faisal, 2014; Sukendar, 2015).

The people variable had a significant influence on the brand image of graduate education. The increase in students' perceptions of graduate education people made the brand image of graduate education of IPB stronger. Indicators of people that contribute most to people variable were qualifications and competence of lecturers. Different results were found in a study by Wibisono (2014) that people had a significant influence on university image. The result showed that people had a significant influence, but not directly on the student's motivation. The people had a significantly positive and indirect impact on the student's motivation. This result can be interpreted that the students took less consideration of the human resources in choosing graduate education. Rahardjo and Firdaus (2016) stated that there was an influence of the variable of people on student motivation.

The result also showed that the human resources of graduate education had a positive but not significant relationship to the student's decision, both directly and indirectly. However, based on the result of the study, it was shown that people had a positive influence and a significant influence on student's decisions. This may imply that people influenced students in making the decision. This result was in accordance with a study Sefnedi (2013), Irawan and Faisal (2014), Sukendar (2015), and Podungge et al. (2016). In other studies, it was shown different results, that people variable did not significantly influence the decision to choose (Yenida et al., 2015).

The result showed that the physical evidence had a positive and significant relationship with the brand image of graduate education. This indicated that the physical evidence had a significant influence on the formation of a brand image. Students had a 
good perception of the physical evidence to form attitudes that reinforce brand image in the minds of students. The same result was found by Wibisono (2014) and Kurniatun and Rosalin (2018) that physical evidence had a significant influence on the university image.

The result showed that the physical evidence had a direct effect on the student's motivation, which was not significant, but it had a significant indirect effect on the student's motivation through brand image. This can be explained that the students were a lack of information about the physical environment of IPB, so it did not affect the student's motivation. However, respondents had a good perception of the brand image of graduate education. This perception contributed to the increasing student's motivation. Rahardjo and Firdaus (2016) stated that there was an effect of physical appearance variables on student motivation.

This study showed that the physical evidence did not significantly influence the student's decision. This showed that the respondents did not consider the physical evidence of the graduate education of IPB in the process of making decisions. Respondents felt that the physical evidence was not an important criterion to be considered in making a decision, but there were other factors more important, like motivation and promotion. The same research results were found in the research of Sefnedi (2013). The study by Kurniawati (2013), Hariyani and Sartana (2014), and Zain et al. (2015) found a different result that educational facilities had a significant influence on the decision of prospective students.

The brand image of graduate education was the belief formulated by someone about the products and services of graduate education. The result showed that the brand image had a significant influence on the student's motivation. Respondents had a strong perception of the brand image of graduate education of IPB that encouraged the respondents' motivation to attend graduate school at IPB. The results of this study that the university image affects student motivation in line with research Sawaji et al. (2010) and Solikhah et al. (2016).

The result showed that the brand image had no significant direct effect on the student's decision, but had a significant indirect effect on the student's decision through motivation. This indicated that the brand image was not an important factor for students to be considered when making decisions. However, the brand image had a strong influence on the increase of motivation of the graduate students of IPB. This strong motivation implied to the increasingly strong tendency of students to decide to choose the study in the graduate education of IPB. Winarti (2014) shown that the university image did not significantly influence the decision to choose the university. Research conducted by Sawaji (2019), Solikhah et al. (2016), and Sunariani (2017) show different results, namely the university's image influences students in choosing universities.

The study result indicated that the student's motivation continued the study at the graduate school had a significant effect on the student's decision to continue the study at graduate education. The result also showed that student's motivation was the most influential factor in the student's decision to choose the graduate education of IPB. The indicator that provides the greatest contribution to the motivation variable is studying in the best study program of interest.

A study by Tereza (2013) showed that the difference in the underlying motivation of students to pursue higher education had a positive influence on university choice to continue the study. The results of Skatova and Ferguson's research (2014) show that differences in student motivation to pursue undergraduate education affect 
university degree choices. The results of research that show that student motivation influences student choices are also found in the research of Sawaji (2019) and Solikhah et al. (2016).

This study has several limitations. the sample used was active students of the master's program, so most of the samples knew the application of the graduate education marketing mix. This can lead to this research being unable to fully explain what marketing mix variables are considered by students when making decisions. This research is limited to the marketing mix, brand image, and student motivation variables so that this research has not been able to fully describe all the factors that influence student decisions.

\section{Conclusion and Recommendation}

\section{Conclusion}

The brand image was directly influenced significantly by the product, promotion, human resources, and physical environment. Variable of motivation was directly influenced significantly by product, promotion, location, and brand image, as well as indirectly influenced significantly by the variables of human resources and physical environments through brand image. Variables of promotion and motivation had a significant direct effect on the decision to choose, while product, processes and brand image had a significant indirect effect on the decision to choose through brand image and/or motivation.

Managerial implications in this study are determined by interpreting the results of the influence analysis. Variables of the marketing mix that have a significant total effect on the decision to vote are variables that are prioritized for use in developing strategies, namely products, promotions, processes, and people.

\section{Recommendation}

Based on the study, managerial implications that can be considered by IPB University in compiling graduate education marketing strategies as an effort to improve brand image, motivation and decision to choose IPB graduate education are as follows:

(1) Product strategy, namely all graduate study programs include curriculum development that supports the development knowledge and needs of the world of work and combining theory and its application, increasing or maintaining accreditation status, and increasing the quantity and quality of research; (2) People's strategy (human resources), which is making programs to improve and develop lecturers' qualifications and competencies in the application of science and technology, as well as the ability and professionalism of lecturers in guiding research; (3) Promotion strategy which is making a graduate education promotion program through internet and social media, both in terms of appearance, ease of access, and quality of information about IPB graduate education and can be accounted for; and (4) Process Strategy, which is developing learning standards and procedures, and a thesis research process that is clear, planned and running well.

Based on the study, further research is expected to complement this research, among others by using a sample of prospective students who have registered or are new. This can better illustrate the conditions when students make decisions in choosing higher education services. In addition, further research can use other variables deemed 
appropriate to make higher education service choices or deepen variables that use other indicators.

\section{References}

Armeilia, D., Simanjuntak, M., Amanah, S. (2019). Determination of Student Decision Factors In Choosing Study Programs In The Faculty Of Public Health At Andalas University, Indonesia. Russian Journal of Agricultural and Socio- Economic Sciences, 91 (7) : 46-57. http://dx.doi.org/10.18551/rjoas.2019-07.06

Arthur, K. M., Asmara, A., \& Simanjuntak, M. (2019). The Effect Of Marketing Mix On "Kpr Xtra Bebas" Decision Making In Bank X Regional I. Journal of Consumer Sciences, 4(1) : 1-12. https://doi.org/10.29244/jcs.4.1.1-12

Constantin, C. (2011). The need of relationship marketing in higher education. Bulletin of the Transilvania University of Brasov. 4(2), 9-26. Retrieved from https://core.ac.uk/download/pdf/27132795.pdf

Dao, M.T.N., \& Thorpe, A. (2015). What factors influence Vietnamese students' choice of university?. The International Journal of Educational Management, 29 (5), 666-681. doi:10.1108/IJEM-08-2014-0110.

Filip, A. (2012). Marketing theory applicability in higher education. Procedia-Social and Behavioral Sciences, 46, 912-916. doi: 10.1016/j.sbspro.2012.05.223.

Ghozali, I. (2008). Structural Equation Modeling Alternative Methods with Partial Least Square. Semarang, Indonesia: Universitas Diponegoro Publisher.

Hariyani, R., \& Sartana, B. T. (2014). The influence of brand image, location, and educational facilities on the decision of prospective students to study at the Budi Luhur University and Academy of Secretaries in the academic year 2014/2015. Journal of Economics and Management, 3(2), 161-175. Retrieved from http://fe.budiluhur.ac.id/wp-content/uploads/2015/11/5b_Reni-Hariyani.pdf

Hermanda, A., Sumarwan, U., \& Tinaprilla, N. (2019). The effect of social media influencer on brand image, self-concept, and purchase intention. Journal of Consumer Sciences, 4(2), 78-69. doi: 10.29244/jcs.4.2.76-89 http://portal.widyamandala.ac.id/jurnal/index.php/warta/article/view/137

Irawan, A., \& Faisal, I. (2014). Analysis of the effect of the service marketing mix on the decision to choose a study program (Study at the Department of Accounting and Department of Business Administration at Banjarmasin State Polytechnic). Journal of Management Insights, 2(2), 155-170 . doi: 10.20527/jwm.v2i2.25

Kurniawati, D. (2013). The influence of the marketing mix strategy on student decisions to choose Widya Mandala Madiun Catholic University. Widya Warta, 2 (1), 65 80. Retrieved from

Maringe, F. (2006). University and course choice implications for positioning, recruitment, and marketing. International Journal of Educational Management, 20(6), 467-479. doi: 10.1108/09513540610683711.

Ming, J.S.K. (2010). Institutional factors influencing students' college choice decision in Malaysia: A conceptual framework. International Journal of Business and Social Science, 1(3), 53-58. doi: 10.30845/ijbss

Podungge, I., Bachri, S., \& Zahara, Z. (2015). The effect of the service marketing mix on student decisions to choose STMIK Bina Mulia Palu. Catalogist E-Journal, 3(10), $59-70$ Retrieved from http://jurnal.untad.ac.id/jurnal/index.php/Katalogis/article/view/6439 
Putlia, G., \& Ihalau, J.J.O.I. (2017). Push and pull factors for prospective students to choose higher education services: Flashback study. Journal of Business \& Applied Management, 9(2), 189-2020. doi: 10.30813/jbam.v9i2.860

Rahardjo, S., \& Firdaus, M.R. (2015). Analysis of the influence of the marketing mix of socioeconomic status and motivation on student decisions in choosing college (Study at the Indonesian Institute of Education and Professional Development (LP3I) Business College - Banjarmasin Branch). Insight Journal Management, 3 (1): 46-59. doi: 10.20527/jwm.v3i1.12

Samani, F.S., Hashemi, S.M., Shahbazi, V., \& Sarhadi, H. (2017). Investigating the relationship between marketing mix elements (7ps) and Iranian EFL learners'choice of langugae institutions. European Journal of Foreign Language Teaching, 2(1), 103-116. doi: 10.46827/ejfl.v0i0.540.

Sawaji, J. (2019). The impact of the image of higher education in order to increase student motivation, attitudes, and decision making in choosing private universities in South Sulawesi. Journal of Business Management, 6(2), 69-76. doi: 10.33096/jmb.v6i2.306

Sawaji, J., Hamzah, D., \& Taba, I. (2010). Making student decisions in choosing private universities in South Sulawesi. Retrieved from http://pasca.unhas.ac.id/jurnal/files/UR93eafc626f1884778a6b787f77c1832b.pdf

Sefnedi. (2013). Analysis of the service marketing-mix and its influence on the decision to choose postgraduate educational services. E-Journal of Economic Appreciation, 1(2), 64-76. doi: 10.31846/jae.v1i2.45.

Simanjuntak, M., Sumarwan, U., \& Situmorang, A.D. (2020). The Effect of Marketing Mix and Brand Image on Customer Loyalty of Remixed Mortar. Independent Journal Of Management \& Production (IJM\&P), 11 (2) : 450-472. DOI: 10.14807/ijmp.v11i2.963

Skatova, A., \& Ferguson, E. (2014). Why do different people choose different university degrees? Motivation and the choice of degree. Frontiers in Psychology, 5(1244). doi: 10.3389/fpsyg. 2014.01244.

Solikhah, A., Hartoyo, \& Yuliati, L.N. (2016). The influence of personality, motivation, brand image, and environment on students' intention in choosing Bogor Agricultural University (IPB). Journal of Consumer Sciences, 1(1), 14-32. doi: 10.29244/jcs.1.1.14-32.

Subramaniam, I.D., Yusoff, W.F.W., \& Arumugam, T. (2014). Needs analysis survey of MBA students: A case study. International Journal of Business and Management, 9(6). doi: 10.5539/ijbm.v9n6p77.

Subramaniam, I.D., Yusoff, W.F.W., \& Othman, N.S. (2014). Communication source, brand image, and brand choices of postgraduate students. International Journal of Business and Management, 9(12), 94-104. doi: 10.5539/ijbm.v9n12p94.

Sukendar, M.U. (2015). The influence of the marketing mix strategy on the decision to choose college students of the D-3 Multimedia-Based Communication study program at Indonusa Polytechnic, Surakarta. The Journal Icon, 1(2), 18-27.

Sumarwan, U. (2015). Consumer Behavior: Theory and its Application in Marketing. Jakarta, Indonesia: Penerbit Ghalia Indonesia.

Sunariani, N.Y. (2017). Marketing mix dan akreditasi terhadap keputusan memilih dengan brand image sebagai variabel intervening. Jurnal Ilmiah Manajemen \& Bisnis, 2(2), 368-377. doi: 10.38043/jimb.v2i2.2090 
Tereza, N. (2013). Analysis and comparison of factors influencing university choice. Journal of Competitiveness, 5(3), 90-100. doi: 10.7441/joc.2013.03.07.

Wandy, J., \& Dharmayanti, D. (2014). Analysis of the effect of the marketing mix on consumer buying interest for Mie Lopo Timor products through motivation as an intervening variable. Petra's Journal of Marketing Management, 2(1), 1-10. Retrieved from http://publication.petra.ac.id/index.php/manajemenpemasaran/article/view/2602

Wibisono, K. (2014). The influence of price, people, process, and physical evidence on brand image. MIX Journal, 4(2), 249-259. doi: 10.22441/jurnal_mix

Winarti, E. (2014). Analysis of the influence of educational services marketing mix factors on image formation and the decision to choose PTAIN: Study at UIN in East Java (Undergraduate Thesis, UIN Maulana Malik Ibrahim, Malang, Indonesia). Retrieved from http://etheses.uinmalang.ac.id/3270/1/12710050.pdf.

Yenida, Sumiarti, \& Sarmiadi, E. (2017). Analysis of the influence of the marketing mix strategy, the higher education system, accreditation status on student decisions in choosing the Department of Commercial Administration of the State Polytechnic of Padang. Management and Entrepreneurship, 5(1), 12-22. Retrieved from http://ojs.unitas-pdg.ac.id/index.php/manajemen/article/view/178

Zain, O.M., Jan, M.T., \& Ibrahim, A.B. (2013). Factors influencing students' decisions in choosing private institutions of higher education in Malaysia: A structural equation modeling approach. Asian Academy of Management Journal, 18(1), 7590. Retrieved from http://eprints.usm.my/36590/1/AAMJ180205.pdf 